\title{
Immiscible iron- and silica-rich liquids in the Upper Zone of the Bushveld Complex
}

\author{
Lennart A. Fischer ${ }^{\mathrm{a}, \mathrm{b}, *}$, Meng Wang ${ }^{\mathrm{a}}$, Bernard Charlier ${ }^{\mathrm{a}, \mathrm{c}}$, Olivier Namur ${ }^{\mathrm{a}}$, \\ R. James Roberts ${ }^{d}$, Ilya V. Veksler ${ }^{\mathrm{e}, \mathrm{f}}$, R. Grant Cawthorn ${ }^{\mathrm{g}}$, François Holtz ${ }^{\mathrm{a}}$ \\ a Institut für Mineralogie, Leibniz Universität Hannover, 30167 Hannover, Germany \\ b School of Physical Sciences, University of Tasmania, Hobart 7001, Australia \\ c Department of Geology, University of Liege, 4000 Sart Tilman, Belgium \\ d Department of Geology, University of Pretoria, Hatfield, Pretoria, 0002, South Africa \\ e Department of Mineralogy and Petrology, Technical University Berlin, 13355 Berlin, Germany \\ ${ }^{f}$ Perm State University, Geological Department, Bukireva 15, 614990 Perm, Russia \\ ${ }^{g}$ School of Geosciences, University of the Witwatersrand, PO Wits 2050, South Africa
}

\section{A R T I C L E I N F O}

\section{Article history:}

Received 19 October 2015

Received in revised form 7 March 2016

Accepted 8 March 2016

Available online $\mathrm{xxxx}$

Editor: M. Bickle

\section{Keywords:}

layered intrusion

melt inclusion

apatite

troctolite

immiscibility

Bushveld

\begin{abstract}
A B S T R A C T
The Bushveld Complex (South Africa) is the largest layered intrusion on Earth and plays a considerable role in our understanding of magmatic differentiation and ore-forming processes. In this study, we present new geochemical data for apatite-hosted multiphase inclusions in gabbroic cumulates from the Bushveld Upper Zone. Inclusions re-homogenized at high-temperature $\left(1060-1100^{\circ} \mathrm{C}\right)$ display a range of compositions in each rock sample, from iron-rich (35 wt.\% $\mathrm{FeO}_{\text {tot }} ; 28 \mathrm{wt} . \% \mathrm{SiO}_{2}$ ) to silica-rich ( $5 \mathrm{wt} . \% \mathrm{FeO}_{\mathrm{tot}} ; 65 \mathrm{wt} . \% \mathrm{SiO}_{2}$ ). This trend is best explained by an immiscible process and trapping of contrasted melts in apatite crystals during progressive cooling along the binodal of a two-liquid field. The coexistence of both Si-rich and Fe-rich immiscible melts in single apatite grains is used to discuss the ability of immiscible melts to segregate from each other, and the implications for mineral and bulk cumulate compositions. We argue that complete separation of immiscible liquids did not occur, resulting in crystallization of similar phases from both melts but in different proportions. However, partial segregation in a crystal mush and the production of contrasting phase proportions from the Fe-rich melt and the Si-rich melt can be responsible for the cyclic evolution from melanocratic (Fe-Ti-P-rich) to leucocratic (plagioclase-rich) gabbros which is commonly observed in the Upper Zone of the Bushveld Complex where it occurs at a vertical scale of 50 to $200 \mathrm{~m}$.
\end{abstract}

(C) 2016 Elsevier B.V. All rights reserved.

\section{Introduction}

Silicate liquid immiscibility and the unmixing of an iron-rich silicate melt and a silica-rich silicate melt has been identified in tholeiitic and andesitic magmas, both in volcanic settings (e.g. Philpotts, 1982; Charlier et al., 2013) and in plutonic environments (e.g. Jakobsen et al., 2005; Namur et al., 2012; Kamenetsky et al., 2013; Veksler and Charlier, 2015). In the case of the Bushveld Complex, South Africa (Fig. 1), the development of immiscibility has been suggested to occur in the Upper Zone (UZ). Reynolds (1985) and von Gruenewaldt (1993) suggested that the numerous (up to $\mathrm{m}$ scale) magnetitite and nelsonite layers in the UZ formed from an immiscible Fe-rich liquid. Scoon and Mitchell (1994) in-

\footnotetext{
* Corresponding author at: Institut für Mineralogie, Leibniz Universität Hannover, 30167 Hannover, Germany.

E-mail address: 1.fischer@mineralogie.uni-hannover.de (L.A. Fischer).
}

terpreted the occurrence of Fe-rich pegmatites in the Upper Critical Zone and the Lower Main Zone as having crystallized from an immiscible Fe-Ti-rich silicate melt derived from the UZ. This model was challenged by Cawthorn (2015) who presented several physical and chemical reasons for its implausibility. Based on a detailed study of rare earth element (REE) concentrations in apatite, VanTongeren and Mathez (2012) suggested a large-scale immiscibility process in the UZ, with a complete physical separation of the buoyant Si-rich melt from the dense Fe-rich melt. Data were re-interpreted by Cawthorn (2013a) who suggested that compositional variability in apatite results from re-equilibration with interstitial liquid in the crystal mush. The role of large-scale immiscibility on the differentiation of the Bushveld UZ has been further debated (Cawthorn, 2014; VanTongeren and Mathez, 2014) but consensus has not yet arisen, mainly because of the absence of any direct evidence for the existence of melts in cumulate rocks. This debate highlights the large uncertainty regarding the signifi- 


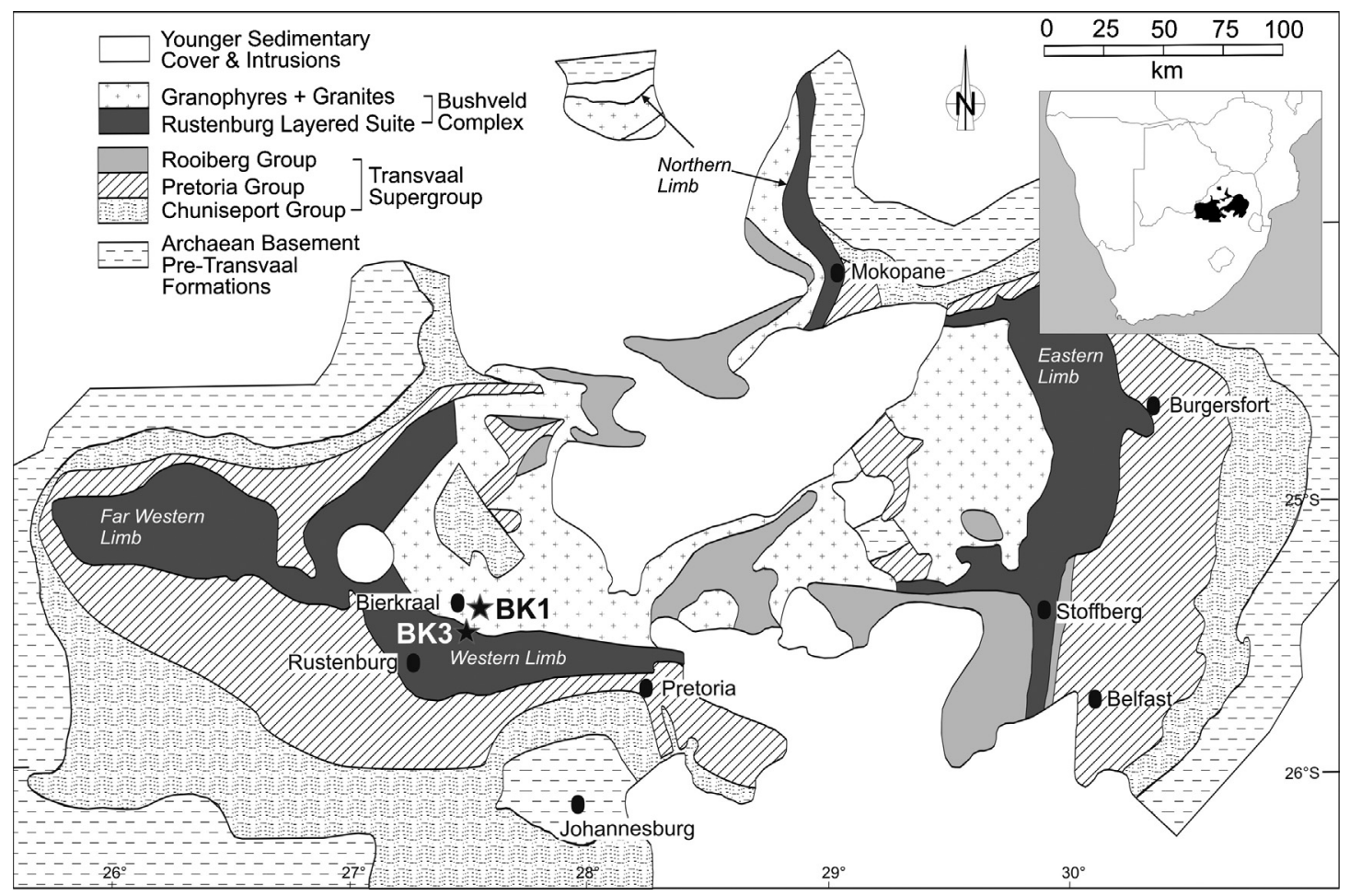

Fig. 1. Geological map of the Bushveld Complex with location of BK1 and BK3 drill-cores (modified after Barnes and Maier, 2002).

cance of liquid immiscibility for magma differentiation in plutonic settings.

In this study, we investigated the petrography of polycrystalline apatite-hosted melt inclusions that we interpret as crystallized melt inclusions. For selected samples, we re-homogenized the inclusions at high temperature and measured their major element compositions. Based on these data, we present the first evidence for the coexistence of immiscible melts during the crystallization of the UZ of the Bushveld Complex. The coexistence of immiscible melts within gabbroic rocks formed by magma at the transition between basaltic and rhyolitic magmatism has implications for the dynamics of magma chambers, the density distribution of silicate melts and cumulate rocks, and the ore-forming processes of Fe-Ti-P-rich layers. This has also implications for the formation of evolved lavas (quartz monzonitic and rhyolitic compositions), which are closely associated to the Bushveld (Mathez et al., 2013; Cawthorn, 2013b).

\section{The Upper Zone of the Bushveld Complex}

The Bushveld Complex, South Africa (Fig. 1), includes a $7 \mathrm{~km}$ thick mafic cumulate sequence emplaced in three limbs. These cumulates are divided into the Marginal, Lower, Critical, Main, Upper and Roof Zones and their corresponding subdivisions (Wager and Brown, 1968). The base of the UZ (subzone UZa) is defined by the appearance of cumulus titanomagnetite, which is followed by the appearance of olivine (UZb) and finally apatite (UZc). The initial emplacement of magma in the Bushveld occurred at $2055.91 \pm 0.26 \mathrm{My}$, and the whole intrusion cooled to below $650^{\circ} \mathrm{C}$ in $1.02 \pm 0.63 \mathrm{My}$ (Zeh et al., 2015). Cawthorn and Walraven (1998) proposed an even shorter crystallization time of $200000 \mathrm{yr}$.

The Upper Zone and Upper Main Zone above the Pyroxenite Marker (hereinafter referred to as UUMZ) are generally considered as having crystallized from a single batch of magma following a large event of magma chamber replenishment (Cawthorn et al., 1991; Tegner and Cawthorn, 2010; VanTongeren and Mathez, 2013).

The UUMZ interval is famous for the occurrence of numerous layers of magnetitite and nelsonite (Molyneux, 1974; von Gruenewaldt et al., 1985; von Gruenewaldt, 1993), the major World resource for vanadium. Tegner et al. (2006) identified 26 magnetite and 6 nelsonite layers in the UZ in the western limb of the Bushveld Complex. Crystallization of abundant Fe-rich minerals drove residual liquids towards $\mathrm{SiO}_{2}$-enrichment (Tegner et al., 2006; Tegner and Cawthorn, 2010). The roof sequence of the Bushveld is poorly defined and the uppermost rocks of the layered intrusion could be either quartz monzonites (Cawthorn, 2013b) or mafic cumulates if evolved residual melts were erupted from the magma chamber (Tegner et al., 2006; VanTongeren et al., 2010).

Although there is a distinct overall differentiation up-section in the UUMZ (Fig. 2), compositional reversals in minerals and significant changes in bulk rock chemistry were described, possibly indicating multiple events of magma replenishment (von Gruenewaldt, 1973; Molyneux, 1974; Ashwal et al., 2005; Scoon and Mitchell, 2012). Tegner et al. (2006) defined nine cyclic units based on whole-rock and mineral compositions (whole-rock $\mathrm{P}_{2} \mathrm{O}_{5}$ content, anorthite in plagioclase, $\mathrm{Mg \#}$ in pyroxenes and olivine, and $\mathrm{V}_{2} \mathrm{O}_{5}$ in magnetite). Six cycles with apatite-bearing rocks (nelsonites, gabbros) occur in the upper half of the UZ (Fig. 2) of the western Bushveld (subzone UZc). In each of these cycles (50 to 200 m-thick), $\mathrm{P}_{2} \mathrm{O}_{5}$ in the whole-rock first increases from very low concentrations ( $<0.2 \mathrm{wt} \%$ ) up to $10 \mathrm{wt} . \%$ (23 wt.\% apatite) and then decreases continuously upwards to 0.5 wt.\% (Fig. 2).

It is commonly assumed that evolved, rhyolitic magma escaped from the Bushveld magma chamber during the late stages of differentiation (Cawthorn and Walraven, 1998; Tegner et al., 2006; VanTongeren et al., 2010). The most recent investigation of the parental magma (VanTongeren et al., 2010) of the UUMZ is based on a careful summation of cumulate compositions to which 15-25 vol.\% of rhyolitic magma (average compositions of the Damwal, Kwaggasnek, Schrikkloof and Rashoop Formations) was added. This amount of rhyolite is required to stabilize orthopy- 

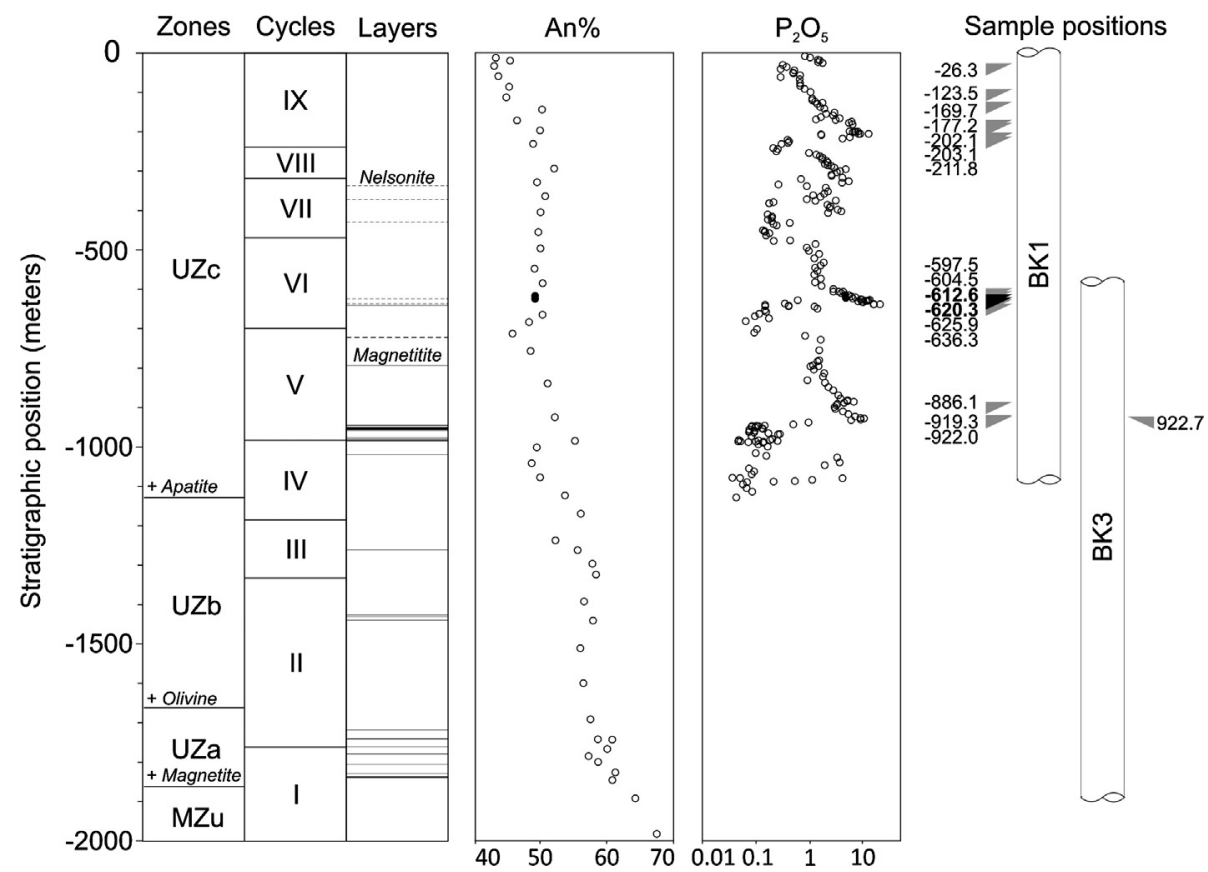

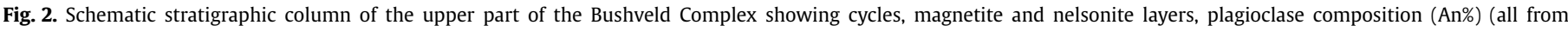

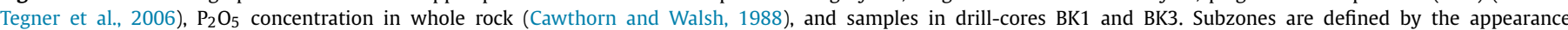

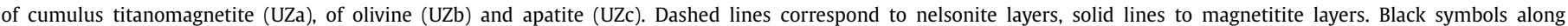

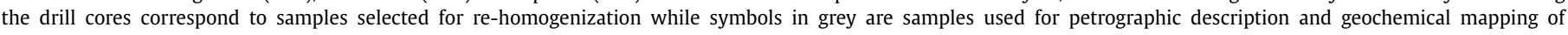
un-homogenized melt inclusions.

roxene, clinopyroxene and plagioclase, which are the first liquidus phases in the UUMZ (Tegner et al., 2006; VanTongeren et al., 2010). Potential parental magmas for the UUMZ are therefore not typical ferrobasalts such as those observed in mid-ocean ridges or continental flood basalts (Charlier et al., 2013). They are enriched in $\mathrm{SiO}_{2}$ (>50 wt.\%), $\mathrm{CaO}$ and $\mathrm{Al}_{2} \mathrm{O}_{3}$, making them more similar to iron-rich tholeiitic andesites.

\section{Methods}

\subsection{Sampling}

The samples selected for this study come from the Bierkraal (BK) drill-cores BK1 and BK3 (Kruger et al., 1987; von Gruenewaldt, 1993; Tegner et al., 2006; Fig. 2), and cover the entire UZc of the western limb of the Bushveld Complex. To correlate samples from both drill-cores we calculated the inferred stratigraphic position for each sample following the equations of Tegner et al. (2006) taking dip angle and roof contact into account.

We have investigated 17 samples from 3 different cycles from the UZc (IX, VI and V; Fig. 2). The rocks can be characterized as Fe-Ti-oxide troctolites, consisting mainly of plagioclase, olivine, Fe-Ti-oxides and apatite as well as minor clinopyroxene (see supplemental Table S1). For all samples, we performed a detailed petrographic examination, including a study of apatite-hosted inclusions. Such inclusions are commonly interpreted to represent equilibrium melts trapped during the growth of their host minerals, and in other intrusions they have been shown to provide unambiguous evidence for the development of immiscibility (Jakobsen et al., 2005; Charlier et al., 2011; Liu et al., 2014). Among studied samples, we selected two rock samples from cycle VI (Tegner et al., 2006) at calculated stratigraphic depths of $-612.6 \mathrm{~m}$ (sample BK1-1085: $1085 \mathrm{~m}$ being the original sample depth in drill-core) and $-620.3 \mathrm{~m}$ (sample BK1-1094), with the ' $0 \mathrm{~m}$ ' reference corresponding to the top of the ferrodioritic cumulates identified at a depth of $415 \mathrm{~m}$ in the BK1 drill-core. In these two rock samples, we re-homogenized apatite-hosted melt inclusions at high tem- perature and performed a detailed geochemical analysis of these inclusions.

\subsection{Re-homogenization of melt inclusions}

Minerals from samples BK1-1085 and BK1-1094 were separated using high voltage pulses with a SELFRAG fragmentation system at the Goethe University Frankfurt. Minerals were then sieved and we kept the fraction with grain sizes between 250 to $1500 \mu \mathrm{m}$, corresponding to the observed sizes of apatite grains. Olivines and Fe-Ti-oxides were separated using a FRANTZ magnetic separator. Apatites were then separated from plagioclase using LST heavy liquid (solution of sodium heteropolytungstates in water; specific gravity: $2750 \mathrm{~kg} / \mathrm{m}^{3}$ ).

Only non-fractured apatite crystals with multiphase inclusions were selected for re-homogenization in an internally heated pressure vessel (IHPV; Berndt et al., 2002). Apatite crystals were loaded in open Pt-capsules together with graphite to reach reducing conditions. The IHPV was pressurized with Ar to a final pressure of $100 \mathrm{MPa}$ and then heated isobarically from $25^{\circ} \mathrm{C}$ to $1060^{\circ} \mathrm{C}$ or $1100^{\circ} \mathrm{C}$ in $2 \mathrm{~h}$. These temperature conditions were necessary to produce crystal-free melt inclusions and correspond to the liquidus temperature of evolved monzonitic magmas (Charlier et al., 2011; Charlier and Grove, 2012). When final temperature was reached, it was held constant for $30 \mathrm{~min}$ before we rapidly quenched the samples on a copper plate. The cooling rate was $\sim 150^{\circ} \mathrm{C} / \mathrm{s}$. Temperature was controlled using two S-type thermocouples (stable within $\pm 2{ }^{\circ} \mathrm{C}$ ) and two additional S-type thermocouples were used to monitor the sample temperature. Temperature gradient across the sample is generally less than $5^{\circ} \mathrm{C}$. Classical melt inclusion homogenization on a heating stage failed at keeping apatite grains from cracking.

\subsection{Analytical method}

Standard thin sections of the rocks were prepared for petrographic and mineral analyses. Individual crystals of apatite were 


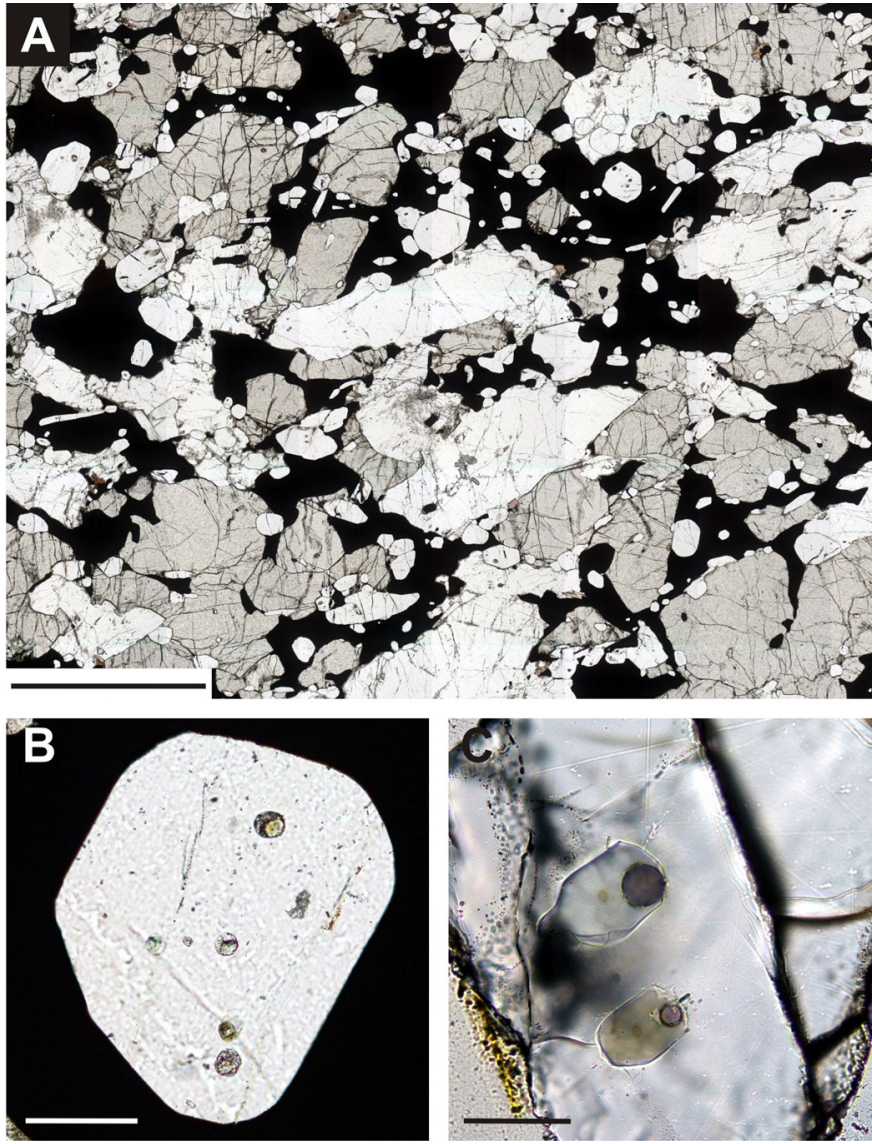

Fig. 3. Microphotographs of apatite-bearing troctolites from the Upper Zone of the Bushveld intrusion, and melt inclusions in apatite. A: Apatite-bearing troctolite (transmitted polarized light; sample BK1-1094); B: Unhomogenized multiphase inclusions trapped in a single grain of apatite (transmitted polarized light; sample BK1-1094); C: Homogenized Si-rich inclusion at the top of the photograph and Ferich inclusion at the bottom of the photograph (transmitted polarized light; sample BK1-1094). Scale bars are $2 \mathrm{~mm}$ (A), $100 \mu \mathrm{m}$ (B), and $50 \mu \mathrm{m}$ (C).

mounted in epoxy and polished to expose the re-homogenized inclusions. The homogenized melt inclusions and minerals were analyzed by electron probe micro-analyzer (EPMA) using a Cameca SX100 at the Institute of Mineralogy in Hannover, Germany. Analyses were conducted with an acceleration voltage of $15 \mathrm{kV}$. Raw data were corrected with the software "Peak Sight" and "PAP" matrix (Pouchou and Pichoir, 1991). Minerals were analyzed with a beam current of $15 \mathrm{nA}$ and a focused beam $(1 \mu \mathrm{m})$. The counting time for each element was $10 \mathrm{~s}$. Glasses were analyzed using a beam current of $4 \mathrm{nA}$ for major elements. The beam size was $5 \mu \mathrm{m}$. The counting time for individual elements varied between 4 and $30 \mathrm{~s}$. The following standards were used: wollastonite for $\mathrm{Si}$ and $\mathrm{Ca}, \mathrm{Al}_{2} \mathrm{O}_{3}$ for $\mathrm{Al}, \mathrm{Fe}_{2} \mathrm{O}_{3}$ for $\mathrm{Fe}, \mathrm{MgO}$ for $\mathrm{Mg}$, rutile for $\mathrm{Ti}$, albite for $\mathrm{Na}$, orthoclase for $\mathrm{K}, \mathrm{Mn}_{3} \mathrm{O}_{4}$ for $\mathrm{Mn}$, apatite for $\mathrm{P}_{2} \mathrm{O}_{5}$. Geochemical mapping of apatite-hosted inclusions before homogenization was performed with a Hitachi SU-70 field emission scanning electron microscope (FE-SEM) and processed with the Oxford Instruments AZtec software at the University of Tasmania.

\section{Results}

\subsection{Petrography of host rocks}

Samples BK1-1085 and BK1-1094 are coarse-grained Fe-Tioxide troctolites, containing mainly plagioclase (modal proportion: $37 \%)$, olivine (26\%), Fe-Ti-oxide (25\%), apatite $(10 \%)$ as well as minor clinopyroxene (2\%) (Fig. 3A). Sulfides, chlorite and biotite occur as accessory minerals. Plagioclase is anhedral to subhedral in shape, ranges in size from 1 to $5 \mathrm{~mm}$ and shows no zoning. The anorthite content is $49 \pm 2 \mathrm{~mol} \%$, similar to the data reported by Tegner et al. (2006) for nearby samples in BK1. Olivine crystals are anhedral to subhedral with a size ranging between 0.5 and $2 \mathrm{~mm}$. Olivines from sample BK1-1094 have a forsterite ( $\mathrm{Fo}=$ molar $100 *[\mathrm{Mg} /(\mathrm{Mg}+\mathrm{Fe})]$; with $\mathrm{Mg}$ and $\mathrm{Fe}$ in molar proportions) content of $\mathrm{Fo}_{26}$ and are slightly more magnesian than those from BK1-1085 $\left(\mathrm{Fo}_{22}\right)$. Olivines from both samples have slightly higher Fo content than olivines from similar depth reported by Tegner et al. (2006). This may be due to diffusive re-equilibration with abundant Fe-Ti oxide minerals (Pang et al., 2009). Fe-Ti oxides (Timagnetite and ilmenite) occur as anhedral patches often associated with apatite. The $\mathrm{TiO}_{2}$ concentration in magnetite varies between 15 and $25 \mathrm{wt} . \%$. Apatites are $0.2-1.5 \mathrm{~mm}$ in size, euhedral in shape and can be characterized as fluorapatite.

\subsection{Petrography of apatite-hosted inclusions}

All 17 studied samples contain apatite grains with abundant multiphase inclusions (Fig. 3B) however, in most samples, apatite crystals are very small $(<200-500 \mu \mathrm{m})$. Single apatite crystals often host several inclusions, locally with different daughter mineral assemblages. Inclusions are rounded to elongated in shape, generally orientated parallel to the crystallographic c-axis of apatite, and their sizes range from $10 \mu \mathrm{m}$ to $100 \mu \mathrm{m}$ (Fig. 3B). The inclusions are fully crystallized and their mineralogy was assessed from multi-element mapping. Elemental maps show that single inclusions contain different minerals in various proportions, the major phases being feldspar, pyroxene, amphibole and olivine (Fig. 4). Minor phases such as ilvaite, chlorite, biotite and Fe-Ti-oxides are locally observed. Feldspars and clinopyroxenes are the dominant phases, whereas chlorite and biotite occur predominantly in inclusions in cracked apatites. We interpret the presence of these hydrous phases as a result of alteration processes in inclusions which were not closed. Crystallized inclusions with highly contrasted mineral modes can be observed in a single apatite grain. Feldspars show a variety of compositions and are mostly present as albite or orthoclase, but can occur with oligoclase to andesine or anorthoclase composition. Olivines have a forsterite content lower than Fo35 but rarely occur as pure fayalite. Crystal boundaries between feldspars are often blurred but sharp to other phases (Fig. 4A). Clinopyroxene shows only minor variations in composition and can mostly be classified as hedenbergite. Orthopyroxene occurs in Ferich inclusions (Fig. 4B) with $\mathrm{Mg} \#$ (molar $[\mathrm{Mg} /(\mathrm{Mg}+\mathrm{Fe})] * 100$ ) ranging between 59 and 71 . Amphiboles show a wide range in composition from calcic- to Mg-amphiboles with relatively high $\mathrm{FeO}$ (Fig. 4C). Ilvaite shows no compositional variations and occurs as small homogeneous crystals.

As illustrated in Fig. 4, inclusions show a large spectrum of daughter phases in different proportions independently of the sample location. Considering the lack of three-dimensional information in geochemical maps (Fig. 4) and the chemical heterogeneity of some crystals, the bulk composition of the inclusions can only be determined from the analysis of glasses obtained after rehomogenization in order to get reliable and unambiguous liquid compositions.

\subsection{Compositions of re-homogenized inclusions}

We studied 99 homogenized melt inclusions in 62 apatite grains from samples BK1-1085 (38 inclusions in 22 apatites) and BK1-1094 (61 inclusions in 40 apatites). Homogenized inclusions show no residual crystal phases and usually contain a gas bubble (Fig. 3C). Chemical profiles across the inclusion-apatite boundary show no compositional gradient. Results of EPMA measurements 

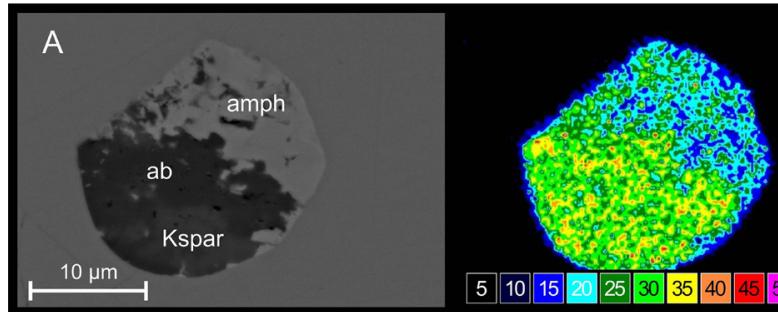

S
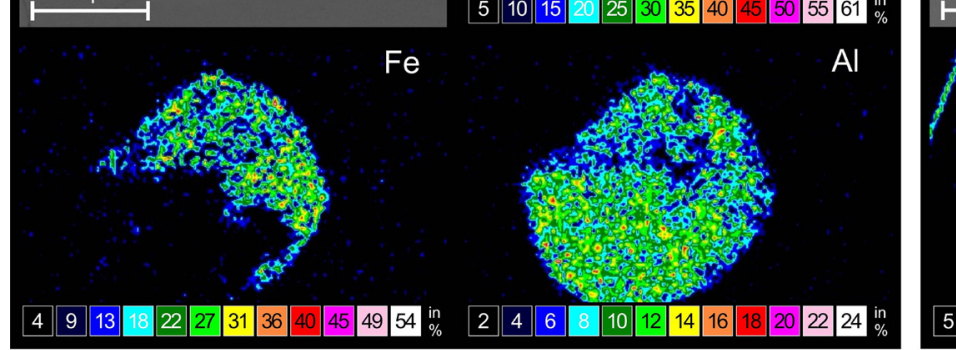
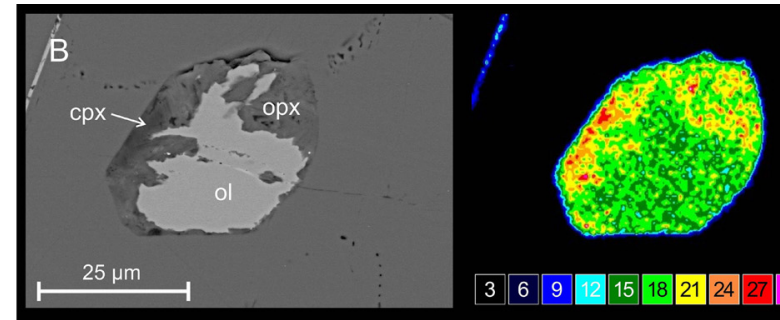

$\mathrm{Si}$

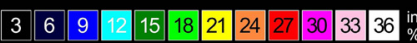
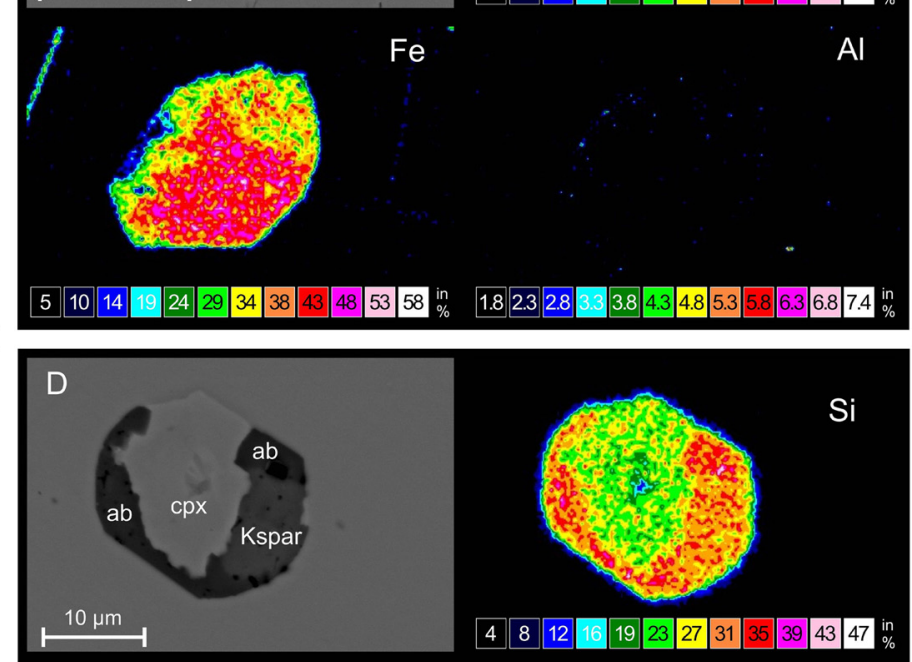

Al

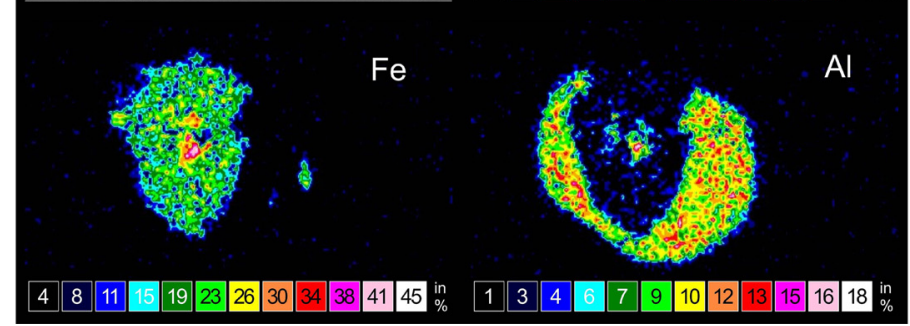

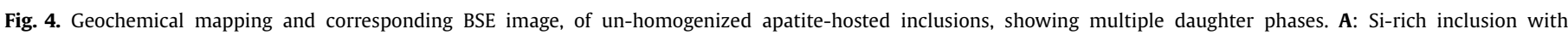

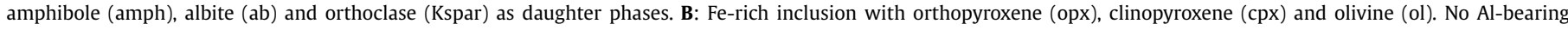

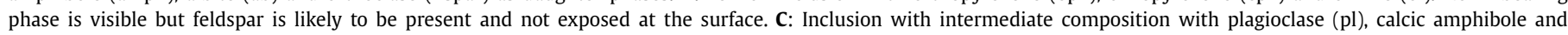
magnesian amphibole. D: Inclusion with intermediate composition with albite, clinopyroxene and orthoclase.

for inclusions are presented in Fig. 5 and supplemental Table S2, in which each melt inclusion is represented by one data point. Inclusions cover a wide compositional range from iron-rich (35 wt.\% $\mathrm{FeO}_{\text {tot }} ; 28$ wt.\% $\mathrm{SiO}_{2}$ ), to silica-rich (5 wt.\% $\mathrm{FeO}_{\text {tot }} ; 65$ wt.\% $\mathrm{SiO}_{2}$ ) (Fig. 5A). Intermediate compositions are also observed but a compositional gap occurs between 40 and 50 wt.\% $\mathrm{SiO}_{2}$ in sample BK1-1094. Multiple inclusions in a single apatite grain always display distinctly contrasted compositions. Overall, $\mathrm{Al}_{2} \mathrm{O}_{3}$ (Fig. 5B), $\mathrm{Na}_{2} \mathrm{O}$ and $\mathrm{K}_{2} \mathrm{O}$ increase linearly with $\mathrm{SiO}_{2}$, whereas $\mathrm{MgO}$ and $\mathrm{P}_{2} \mathrm{O}_{5}$ decrease. $\mathrm{CaO}$ does not show a simple linear trend (Fig. $5 \mathrm{C}$ ). When plotted against $\mathrm{SiO}_{2}$, the $\mathrm{CaO}$ content first increases from 12 to 17 wt.\% with $\mathrm{SiO}_{2}$ increasing from 28 to 39 wt.\%, and then decreases down to 3 wt.\% at 65 wt.\% $\mathrm{SiO}_{2}$. The highest $\mathrm{CaO}$ values that we observe are surprisingly high compared to typical basaltic magmas (e.g. 10-12 wt.\% CaO; Jenner and O'Neill, 2012), ferrobasalts (e.g. 8-10 wt.\% CaO; Toplis and Carroll, 1996; Thy et al., 2009), andesitic magmas (8-11 wt.\% CaO; Wilkinson, 1986) and even Fe-rich immiscible melts (6-14 wt.\% CaO; Charlier et al., 2011; Charlier and Grove, 2012). An obvious reason for this high $\mathrm{CaO}$ content would be substantial melting of apatite during melt inclusion homogenization. However, considering a melt with 40 wt.\% $\mathrm{SiO}_{2}$ and using equations from Harrison and Watson (1984), we calculated that melting above the liquidus from $1050^{\circ} \mathrm{C}$ to $1100^{\circ} \mathrm{C}$ would produce an increase from 3.38 to 3.96 wt.\% $\mathrm{P}_{2} \mathrm{O}_{5}$ in the silicate melt, corresponding to an increase of 0.75 wt.\% $\mathrm{CaO}$. This increase in solubility of apatite with temperature does not explain the extremely high $\mathrm{CaO}$ values of the melt inclusions compared to the estimated $\mathrm{CaO}$ contents of Bushveld UZ magmas $(\sim 10$ wt.\% $\mathrm{CaO}$ at $\mathrm{F}=1$ to $<4$ wt.\% $\mathrm{CaO}$ at $\mathrm{F}=0.2$; with $\mathrm{F}$ being the residual liquid fraction; Tegner et al., 2006).

\section{Discussion}

\subsection{Liquid line of descent and onset of immiscibility}

Daughter phase compositions of the analyzed melt inclusions differ significantly from cumulate mineral compositions. Olivine in inclusions span a very large compositional range $\left(\mathrm{Fo}_{0}\right.$ to $\left.\mathrm{Fo}_{35}\right)$, whereas cumulus olivines show a more restricted range between $\mathrm{Fo}_{22}$ and $\mathrm{Fo}_{26}$. Plagioclase in inclusions is mostly present as albite or orthoclase endmember composition $\left(\sim A n_{0}\right)$, whereas the cumulate plagioclase composition is around $\mathrm{An}_{50}$. This compositional differences between cumulate and daughter minerals imply that the studied inclusions represent crystallized liquid compositions rather than trapped minerals.

The large compositional variations of these melt inclusions may be explained either by the entrapment of liquids reflecting different differentiation stages or by liquid immiscibility. To test the first hypothesis we calculated possible liquid lines of descent (LLD) for the UUMZ with the MELTS thermodynamic algorithm (Ghiorso and Sack, 1995) for 8 different starting compositions at oxygen fugacities $\left(f \mathrm{O}_{2}\right)$ between QFM-1 and +1 (QFM: corresponding to the 

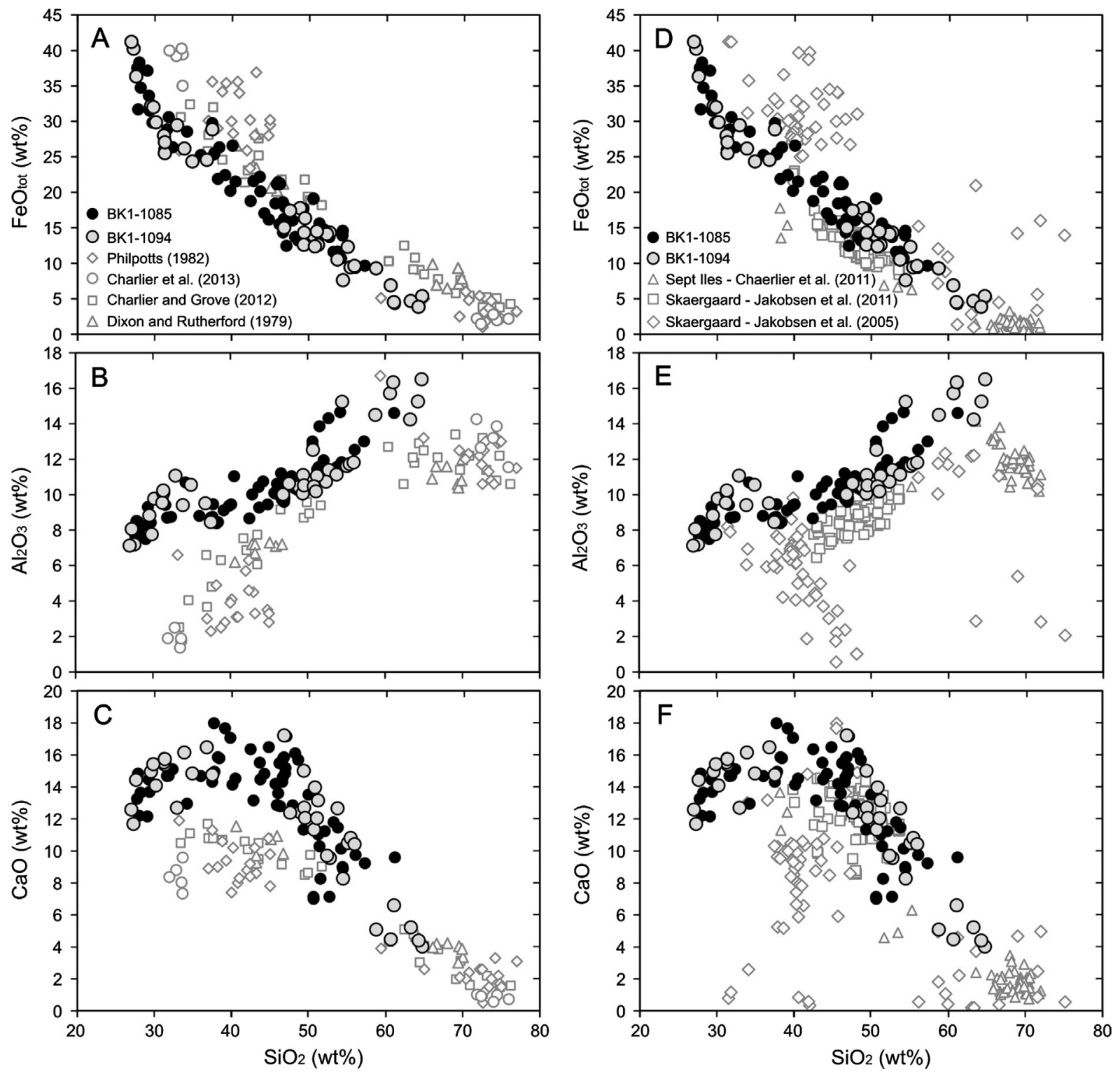

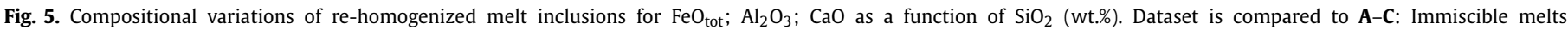

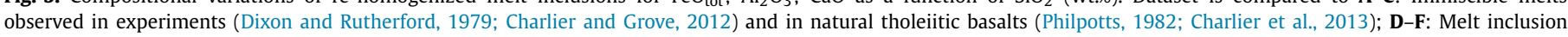
compositions from Skaergaard (Jakobsen et al., 2005, 2011) and Sept Iles (Charlier et al., 2011).

quartz-fayalite-magnetite buffer) and initial $\mathrm{H}_{2} \mathrm{O}$ contents of 0.1 and 1.0 wt.\% (VanTongeren et al., 2010; Fig. 6 and supplemental Fig. S1). The 8 different starting compositions were proposed by VanTongeren et al. (2010) and correspond to a mixture between the bulk composition of the UUMZ and $15-25$ wt\% of various rhyolite melts which are assumed to have escaped from the magma chamber (VanTongeren et al., 2010). According to petrographic study of VanTongeren et al. (2010) we only present LLDs in which orthopyroxene crystallizes as the first cumulus phase (supplemental Fig. S1). Whatever the $\mathrm{fO}_{2}$ conditions, the initial water content and the parent magma used in the calculations, the UUMZ magmas first record a stage of iron-enrichment before titanomagnetite saturation. The maximum $\mathrm{FeO}_{\text {tot }}$ content of the melt at titanomagnetite saturation is usually close to $15 \mathrm{wt} . \%$. After magnetite saturation, residual melts evolved towards $\mathrm{SiO}_{2}$-enrichment and $\mathrm{FeO}$ depletion. Although MELTS may have some limitations in Fe-rich and Si-rich systems (Ghiorso and Sack, 1995), our calculations are in very good agreement with the results obtained by Tegner et al. (2006) and Tegner and Cawthorn (2010) using detailed mass bal- ance calculations between liquid and cumulate rocks and analysis of $\mathrm{FeO}$ in cumulus plagioclase.

Homogenized melt inclusions in apatite show a compositional range much larger than the inferred LLDs (Fig. 6). Evolved melt inclusions with $60-65$ wt.\% $\mathrm{SiO}_{2}$ could have been produced by fractional crystallization of the UUMZ parental magma (Tegner et al., 2006; VanTongeren et al., 2010; Supplemental Fig. S1; Fig. 6) but the iron-rich melts that we observe in melt inclusions plot away from any potential trend of fractional crystallization. This suggests that at least some melts trapped in apatite grains were not produced by a simple fractional crystallization process (Fig. 6). Instead, we interpret the existence of Fe-rich compositions with more than 18 wt.\% FeO as an indication that silicate liquid immiscibility developed during crystallization of the UUMZ. In addition, the large compositional variation of melt inclusions would indicate that the melt inclusions of one sample have been trapped over a temperature interval, as discussed below. Following this reasoning, the evolved, silica-rich melt inclusions, could also have been produced by immiscibility and could represent the conjugate Si-rich melts of 


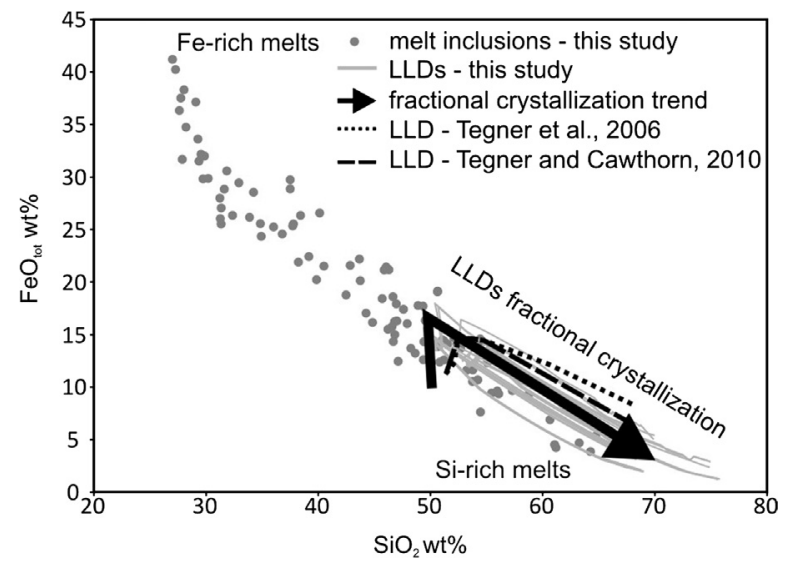

Fig. 6. $\mathrm{FeO}_{\text {tot }}$ (wt.\%) vs. $\mathrm{SiO}_{2}$ (wt.\%) diagram showing potential liquid lines of descent (LLD) for the Upper and Upper Main Zone (UUMZ) of the Bushveld Complex. Grey lines represent results of MELTS calculations (Ghiorso and Sack, 1995) at three different oxygen fugacity conditions (FMQ+1, FMQ and FMQ-1). Dashed black lines represent LLDs from Tegner et al. (2006) and Tegner and Cawthorn (2010). We used 8 starting compositions (see Table S3 and Fig. S1 in the supplement) representing a mixture between the bulk composition of the UUMZ (VanTongeren et al., 2010) and 15-25 wt.\% of a rhyolite formation (Damwal, Kwaggasnek, Schrikkloof and Rashoop). Calculations were performed for initial $\mathrm{H}_{2} \mathrm{O}$ contents of 0.1 and $1.0 \mathrm{wt} . \%$. We only present LLDs for which orthopyroxene crystallizes as the first cumulus phase (VanTongeren et al., 2010). Black arrow outlines the average fractional crystallization trend from the MELTS calculations.

the Fe-rich melt inclusions. In this hypothesis, the calculated LLDs hit the two-liquid field during evolution from iron-rich basaltic andesite to silica-rich compositions leading to the separation of an Fe-rich melt and a Si-rich melt (Charlier and Grove, 2012; Namur et al., 2012; Fig. 7).

Immiscible melt inclusions have also been described in the Skaergaard (Jakobsen et al., 2005, 2011) and Sept Iles layered intrusions (Charlier et al., 2011; Namur et al., 2012). Melt inclusions in Skaergaard are observed in apatite and olivine from the Upper Zone (Jakobsen et al., 2005) and in plagioclase from the top of the Lower Zone (LZc) to the Upper Zone (Jakobsen et al., 2011). Apatite hosted inclusions are larger $(10-200 \mu \mathrm{m})$ compared to those from this study but have a similar appearance. When combined with the plagioclase hosted inclusions, data show a similar continuous Ferich to Si-rich compositional range (Fig. 5D). This was interpreted by Jakobsen et al. (2011) as trapping of droplets of both liquids in different proportions. Charlier et al. (2011) presented inclusions hosted in apatite from the most evolved cumulates of the Sept Iles layered intrusion. Their melt inclusions are similar in shape and size $(10-120 \mu \mathrm{m})$ to the inclusions from this study. Melt inclusions from Sept Iles show a smaller compositional range from 18 wt.\% $\mathrm{FeO}_{\text {tot }}$ and 38 wt.\% $\mathrm{SiO}_{2}$ to 0.5 wt.\% $\mathrm{FeO}_{\text {tot }}$ and $70 \mathrm{wt} . \%$ $\mathrm{SiO}_{2}$ (Charlier et al., 2011), with a complete absence of intermediate compositions.

\subsection{Trapping of melt inclusions and compositional evolution during cooling}

The compositional range that we observe in a single sample is much broader than expected if two immiscible end-members were trapped at a single temperature. Incomplete segregation of two immiscible end-members at a $\mu \mathrm{m}$-scale (e.g. Jakobsen et al., 2011), and trapping of melt along the binodal surface during cooling (e.g. Charlier and Grove, 2012), can result in a wide compositional range for melt inclusions. Simple mixing of different proportions of paired melts produces linear trends for all major elements. Although we observe linear trends for most elements, the behaviour of $\mathrm{CaO}$ cannot be explained by simple mixing of two immiscible poles and as demonstrated above was not significantly affected by

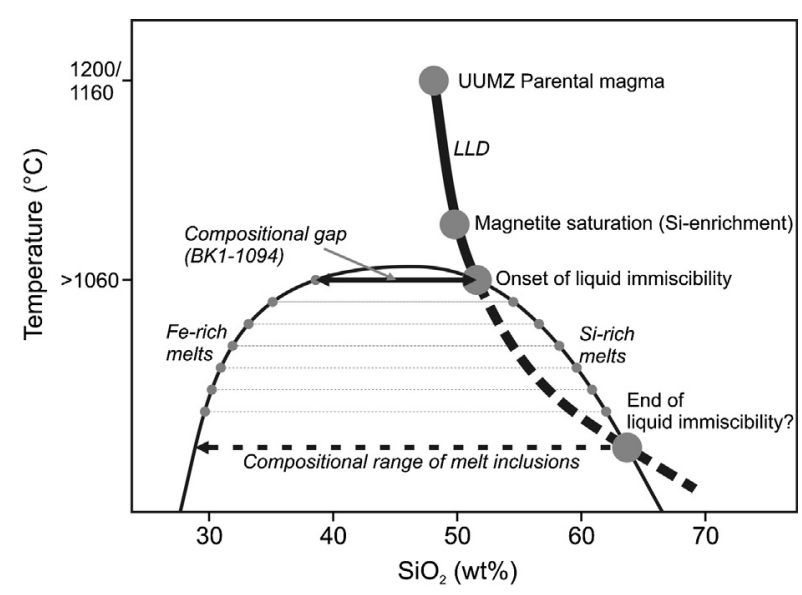

Fig. 7. Schematic liquid line of descent (LLD) for the Bushveld UUMZ parental magma plotted in a temperature (no precise scale) vs. $\mathrm{SiO}_{2}$ (wt.\%) diagram. Upon cooling, the LLD (solid line) becomes saturated in magnetite and then reaches the two-liquid field (onset of immiscibility), below $1060^{\circ} \mathrm{C}$ (minimum temperature for melt inclusion homogenization). Pairs of Fe- and Si-rich melts are then formed. With cooling, the immiscibility field expands and melt pairs become more contrasting in composition. No liquid between 40 and $50 \mathrm{wt} . \% \mathrm{SiO}_{2}$ is produced (compositional gap observed in sample BK1-1094). Intermediate compositions in sample BK1-1085 are explained by incomplete separation of the immiscible melts (Jakobsen et al., 2011). The heavy dashed line represents the evolution of the bulk liquid (Fe-rich + Si-rich). The most contrasting compositions of melt inclusions are reached just before the bulk liquid possibly leaves the two-liquid field.

apatite melting during the experiments. Although we cannot exclude that some melt inclusions represent an emulsion of unsegregated immiscible melts, we suggest that most of the compositional range that we observe is controlled by a temperature-dependent evolution of element partitioning between immiscible melts. This is confirmed by experimental data showing that $\mathrm{CaO}$ partitioning between the Fe- and Si-rich liquids is indeed strongly dependent on temperature, melt composition, and melt structure (Bogaerts and Schmidt, 2006; Charlier and Grove, 2012), which results in a non-linear $\mathrm{CaO}$ vs. $\mathrm{SiO}_{2}$ trend of immiscible pairs (Fig. $5 \mathrm{C}$ ). The expansion of the two-liquid field during cooling is responsible for the formation of increasingly contrasted melts as temperature decreases (Charlier and Grove, 2012). Trapping inclusions along the binodal surface produces a large range of compositions between conjugate melts. Si-rich and Fe-rich melts are presumably close in composition at high temperatures (when the liquid line of descent first hits the solvus) and then become increasingly contrasted as temperature decreases (Fig. 7).

Considering that the range of liquid compositions that we observe represents trapping of melt inclusions at different temperatures rather than trapping an emulsion of immiscible melts, we can use experimental data to estimate the degree of crystal mush cooling during apatite crystallization. Experimental immiscible melt pairs reported in Charlier and Grove (2012) show that, depending on where the LLD hits the binodal surface, it is possible to produce pairs with $60-65$ wt.\% $\mathrm{SiO}_{2}$ and $8-11$ wt.\% $\mathrm{FeO}_{\text {tot }}$ vs. 42-50 wt.\% $\mathrm{SiO}_{2}$ and $19-22$ wt.\% $\mathrm{FeO}_{\text {tot }}$ at $1020^{\circ} \mathrm{C}$, and $73-76$ wt.\% $\mathrm{SiO}_{2}$ and 4-6 wt.\% $\mathrm{FeO}_{\text {tot }}$ vs. 31-36 wt.\% $\mathrm{SiO}_{2}$ and 25-32 wt.\% $\mathrm{FeO}_{\text {tot }}$ at ca. $960^{\circ} \mathrm{C}$. This compositional range is relatively similar to the melt inclusion compositions that we observe, which suggests that melt inclusions were trapped during apatite growth on a temperature interval of $\sim 60^{\circ} \mathrm{C}$. No estimate of liquidus temperature exists for the Bushveld UZ but we note that our calculated interval of $60^{\circ} \mathrm{C}\left(1020-960^{\circ} \mathrm{C}\right)$ is almost identical to that between apatite saturation and the solidus of the Skaergaard magma $\left(1040-980^{\circ} \mathrm{C}\right.$; Thy et al., 2009). We therefore suggest that this temperature interval can realistically span the liquidus temperature down to the complete solidification of the crystal mush. 
A
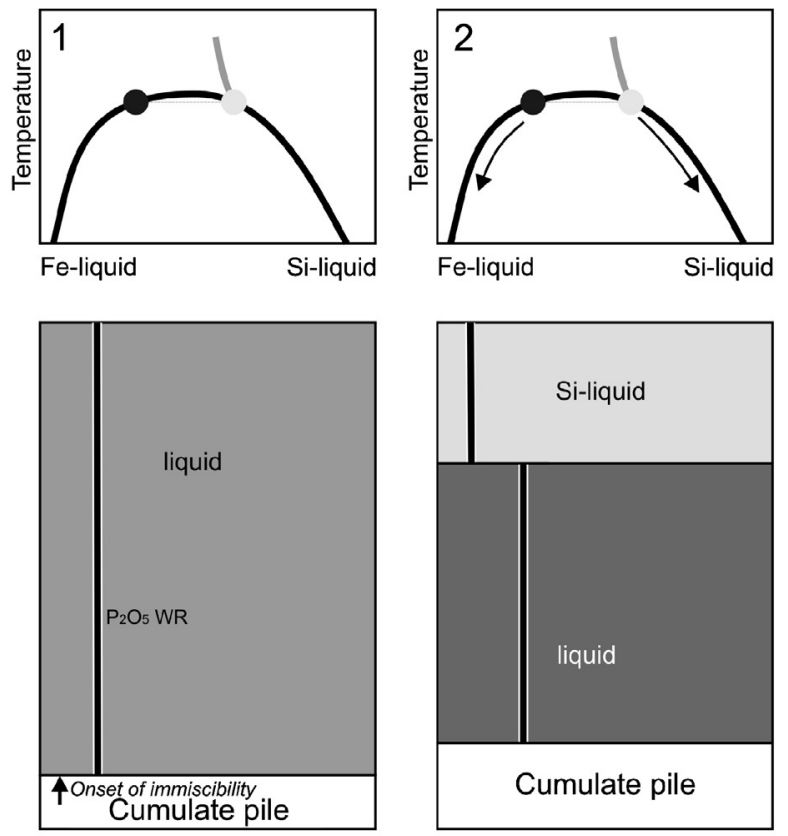

B
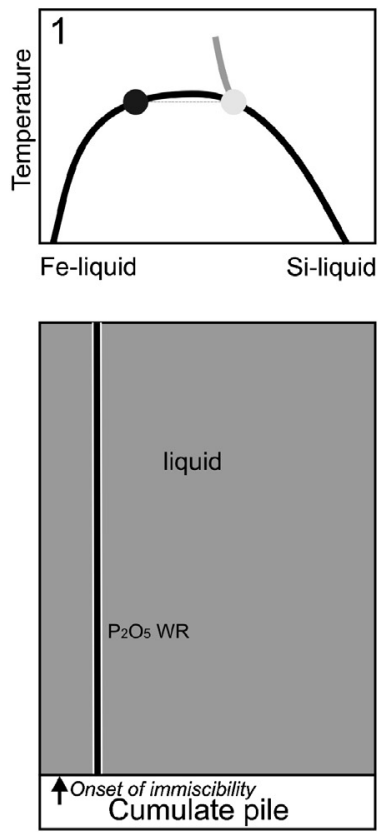

Fe-liquid Si-liquid
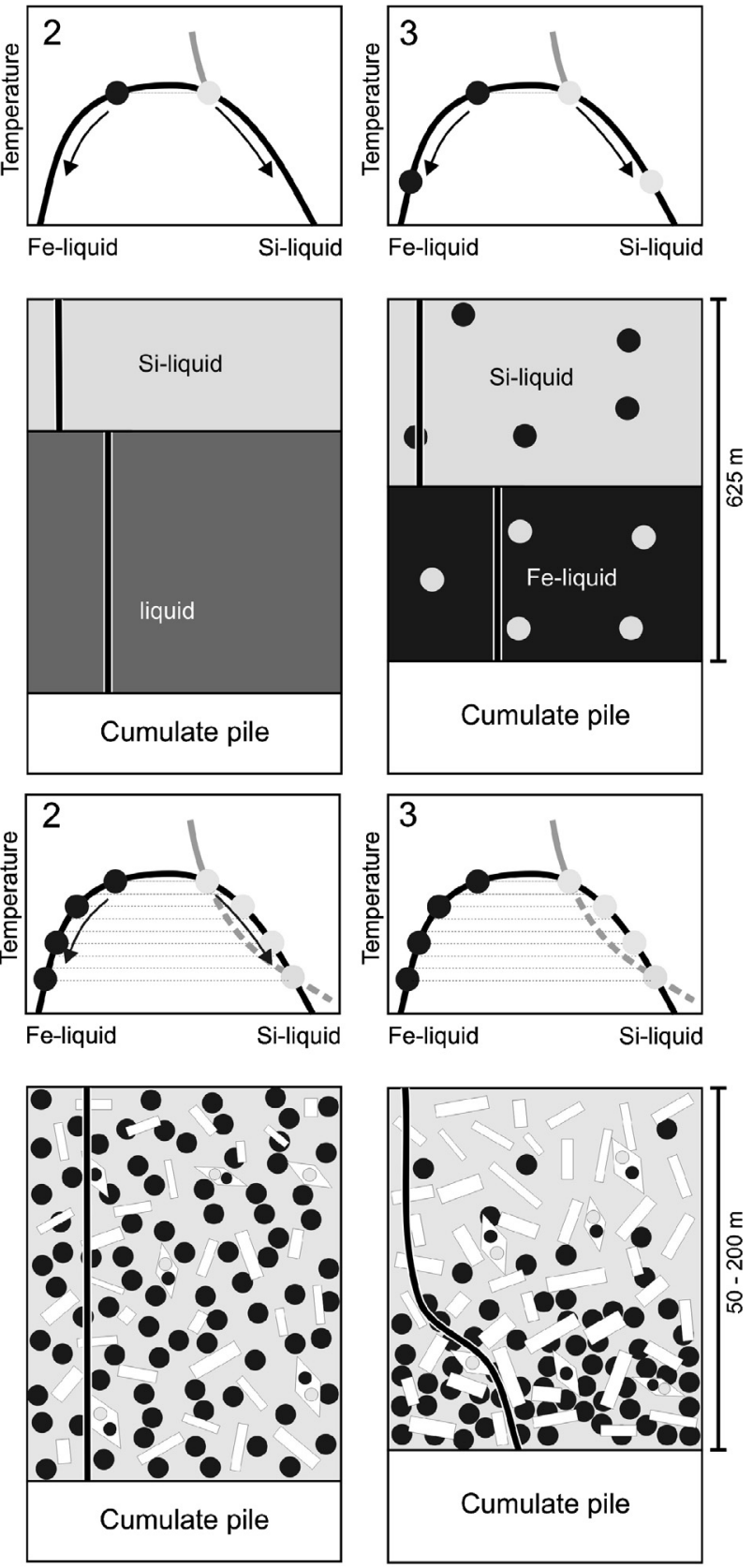

conjugates stay in equilibrium

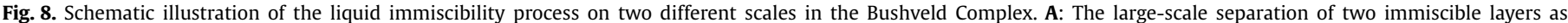

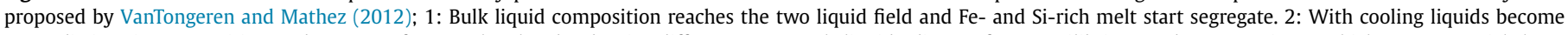

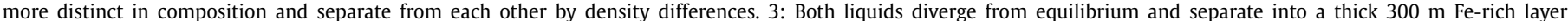

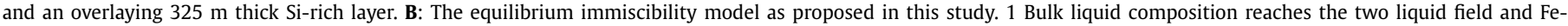

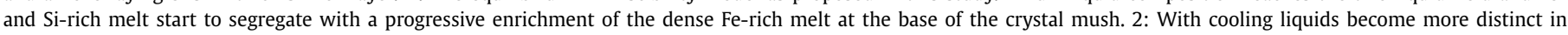
composition but stay in equilibrium 3: Melt droplets are sorted in the crystal mush and crystallized mela- to leucogabbros.

\subsection{Migration of immiscible melts in a crystal mush and formation of layering}

Immiscible Fe-rich and Si-rich pairs have contrasting physical properties, i.e. higher density and lower viscosity for the Fe-rich melt (Philpotts, 1982; Charlier and Grove, 2012; Namur et al., 2015). However, their ability to separate is also dependent on other parameters such as cooling rate, globules coarsening, interfacial tension, and wetting properties with cumulus phases (Martin and Kushiro, 1991; Mungall and Su, 2005; Chung and Mungall, 2009; Veksler et al., 2010), which makes difficult any prediction for a specific plutonic environment. Moreover, owing to the dome-like shape of the immiscibility binodal surface (Fig. 7), if two immiscible liquids form and segregate, each liquid will exsolve its conjugate as the temperature decreases. Consequently, even if perfect segregation of the paired melts is reached at the onset of immiscibility, both liquids will keep evolving on the binodal surface that will continue to diverge with falling temperature.

The hypothesis of large-scale separation of two layers of immiscible melts in the Bushveld Complex, illustrated on Fig. 8A, was based on an abrupt change of the REE content of cumulus apatite between two horizons of the UZ in the eastern limb 
(VanTongeren and Mathez, 2012). This process was inferred to result in the formation of a lower, dense, 300 m-thick, cumulate section with low concentration of REE in apatite, representing the crystallization products of the iron-rich melt, and an upper, buoyant $325 \mathrm{~m}$ cumulate section with REE-rich apatites, formed by crystallization of the silica-rich melt. This model requires that the two melts separate completely and diverge from the equilibrium compositions following their own LLD (VanTongeren and Mathez, 2014). In the western limb, REE data in apatite presented by Cawthorn (2014) show a relatively continuous increase from the most primitive apatite-bearing gabbros to the top of the intrusion. This pattern suggests continuous evolution of the main magma body by fractional crystallization rather than segregation and chemical isolation of two thick layers of immiscible melts (VanTongeren and Mathez, 2012). It is therefore possible that the processes of crystallization in the different limbs of the Bushveld are different which is perhaps suggested by the different bulk rock stratigraphic trends in the western limb (Fig. 1), the northern limb (Ashwal et al., 2005) and the eastern limb (Scoon and Mitchell, 2012). In the western limb where we observe a succession of 200-300 m thick cycles with a bottom made up of melano-gabbro followed by progressively more leuco-gabbroic rocks, we suggest that immiscibility occurred repetitively as already suggested for the Sept Iles layered intrusion (Charlier et al., 2011). Sorting of immiscible melt droplets in the crystal mush led to the development of horizons dominated by Fe-rich melt at the bottom (which mostly crystallized Fe-Ti oxide minerals and apatite) and Si-rich melt at the top (which mostly crystallized plagioclase-rich rocks). Nevertheless, during cooling, Fe-rich and Si-rich liquids stay in equilibrium and minerals with identical compositions but different proportions crystallize from the two liquids. The reversals in mineral compositions (plagioclase An-content and the Mg number of mafic minerals) at the bottom of each cycle could be related to magma chamber replenishments (von Gruenewaldt, 1973; Molyneux, 1974; Ashwal et al., 2005; Scoon and Mitchell, 2012) producing hybrid melts with a bulk composition falling out of the two-liquid field or to a process of density inversion due to instable magma density stratification (Tegner et al., 2006). Successive stages of immiscibility would then be produced by cooling and compositional evolution of the residual melts after each compositional reversal.

\section{Conclusions}

This study of melt inclusions in apatite demonstrates that immiscibility played an important role in the formation of cumulate rocks in the Upper Zone of the Bushveld Complex. Inclusions in apatite are observed in gabbros, troctolites and nelsonites of the entire Upper Zone. The wide range in melt compositions, from iron-rich to silica-rich, is interpreted to be the result of entrapment at different temperatures along the binodal surface. Particularly, the iron-rich compositions observed in this study cannot have been produced by fractional crystallization and thus strongly support an immiscibility process. The sorting of immiscible melt droplets in the crystal mush possibly explains the formation of Fe-Ti-P-rich and (leuco-)gabbroic layers in the Upper Zone of the Bushveld Complex.

\section{Acknowledgements}

This project was supported by a DAAD-Doktorandenstipendium for L.A. Fischer. B. Charlier and O. Namur acknowledge support from the Alexander von Humboldt Foundation. We acknowledge the German Science Foundation for the support of the research work. I.V. Veksler has been supported by DFG grant VE 619/2-1 and RSF grant No. 14-17-00200. The reviews of C. Tegner, J. VanTongeren and an anonymous reviewer helped to improve the quality of this paper. P.E. Wolff and C. Zhang from the Leibniz Universität Hannover, and S. Feig and K. Goemann from the University of Tasmania are thanked for support with EPMA and FE-SEM. We acknowledge C. Glotzbach, C. Wangenheim and L. Lindner, Institut für Geologie, Leibniz Universität Hannover, for providing mineral separation, and A. Woodland and T. Terhaar, Goethe University Frankfurt, for SELFRAG. V.S. Kamenetsky, A. Husen, and S. Sykora are thanked for discussions and their comments.

\section{Appendix A. Supplementary material}

Supplementary material related to this article can be found online at http://dx.doi.org/10.1016/j.epsl.2016.03.016.

\section{References}

Ashwal, L.D., Webb, S.J., Knoper, M.W., 2005. Magmatic stratigraphy in the Bushveld Northern Lobe: continuous geophysical and mineralogical data from the $2950 \mathrm{~m}$ Bellevue drillcore. S. Afr. J. Geol. 108, 199-232.

Barnes, S.-J., Maier, W.D., 2002. Platinum-group element distributions in the Rustenberg Layered Suite of the Bushveld Complex, South Africa. In: Cabri, L.J. (Ed.) The Geology, Geochemistry, Mineralogy and Mineral Beneficiation of PlatinumGroup Elements (Special Volume). Canadian Institute of Mining, Metallurgy and Petroleum, pp. 431-458.

Berndt, J., Liebske, C., Holtz, F., Freise, M., Nowak, M., Ziegenbein, D., Hurkuck, W. Koepke, J., 2002. A combined rapid-quench and H-2-membrane setup for internally heated pressure vessels: description and application for water solubility in basaltic melts. Am. Mineral. 87, 1717-1726.

Bogaerts, M., Schmidt, M.W., 2006. Experiments on silicate melt immiscibility in the system $\mathrm{Fe}_{2} \mathrm{SiO}_{4}-\mathrm{KAISi}_{3} \mathrm{O}_{8}-\mathrm{SiO}_{2}-\mathrm{CaO}-\mathrm{MgO}-\mathrm{TiO}_{2}-\mathrm{P}_{2} \mathrm{O}_{5}$ and implications for natural magmas. Contrib. Mineral. Petrol. 152, 257-274.

Cawthorn, R.G., 2013a. Rare earth element abundances in apatite in the Bushveld Complex-a consequence of the trapped liquid shift effect. Geology 41, 603-606.

Cawthorn, R.G., 2013b. The residual or roof zone of the Bushveld Complex, South Africa. J. Petrol. 54, 1875-1900.

Cawthorn, R.G., 2014. Rare earth element abundances in apatite in the Bushveld Complex-a consequence of the trapped liquid shift effect: REPLY. Geology 42 e319.

Cawthorn, R.G. 2015. The Bushveld Complex, South Africa. In: Charlier, B. et al. (Eds.), Layered Intrusions. Springer, Dordrecht, pp. 517-587.

Cawthorn, R.G., Walsh, K.L., 1988. The use of phosphorus contents in yielding estimates of the proportion of trapped liquid in cumulates of the Upper Zone of the Bushveld Complex. Mineral. Mag. 52 (364), 81-89.

Cawthorn, R.G., Walraven, F., 1998. Emplacement and crystallization time for the Bushveld Complex. J. Petrol. 39 (9), 1669-1687.

Cawthorn, R.G., Meyer, P.S., Kruger, F.J., 1991. Major addition of magma at the Pyroxenite Marker in the western Bushveld Complex, South Africa. J. Petrol. 32, 739-763.

Charlier, B., Grove, T.L., 2012. Experiments on liquid immiscibility along tholeiitic liquid lines of descent. Contrib. Mineral. Petrol. 164, 27-44.

Charlier, B., Namur, O., Toplis, M.J., Schiano, P., Cluzel, N., Higgins, M.D., Vander Auwera, J., 2011. Large-scale silicate liquid immiscibility during differentiation of tholeiitic basalt to granite and the origin of the Daly gap. Geology 39, 907-910.

Charlier, B., Namur, O., Grove, T.L., 2013. Compositional and kinetic controls on liquid immiscibility in ferrobasalt-rhyolite volcanic and plutonic series. Geochim. Cosmochim. Acta 113, 79-93.

Chung, H.-Y., Mungall, J.E., 2009. Physical constraints on the migration of immiscible fluids through partially molten silicates, with special reference to magmatic sulfide ores. Earth Planet. Sci. Lett. 286, 14-22.

Dixon, S., Rutherford, M.J., 1979. Plagiogranites as late-stage immiscible liquids in ophiolite and mid-ocean ridge suites: an experimental study. Earth Planet. Sci. Lett. 45, 45-60.

Ghiorso, M.S., Sack, R.O., 1995. Chemical mass transfer in magmatic processes, IV: a revised and internally consistent thermodynamic model for the interpolation and extrapolation of liquid-solid equilibria in magmatic systems at elevated temperatures and pressures. Contrib. Mineral. Petrol. 119, 197-212.

Harrison, T.M., Watson, E.B., 1984. The behavior of apatite during crustal anatexis: equilibrium and kinetic considerations. Geochim. Cosmochim. Acta 48, 1467-1477.

Jakobsen, J.K., Veksler, I.V., Tegner, C., Brooks, C.K., 2005. Immiscible iron- and silicarich melts in basalt petrogenesis documented in the Skaergaard intrusion. Geology $33,885-888$.

Jakobsen, J.K., Veksler, I.V., Tegner, C., Brooks, C.K., 2011. Crystallization of the Skaergaard intrusion from an emulsion of immiscible iron- and silica-rich liquids: evidence from melt inclusions in plagioclase. J. Petrol. 52, 345-373. 
Jenner, F.E., O’Neill, H.S.C., 2012. Analysis of 60 elements in 616 ocean floor basaltic glasses. Geochem. Geophys. Geosyst. 13 (2).

Kamenetsky, V.S., Charlier, B., Zhitova, L., Sharygin, V., Davidson, P., Feig, S., 2013. Magma chamber-scale liquid immiscibility in the Siberian Traps represented by melt pools in native iron. Geology 41, 1091-1094.

Kruger, F.J., Cawthorn, R.G., Walsh, K.L., 1987. Strontium isotopic evidence against magma addition in the Upper Zone of the Bushveld Complex. Earth Planet. Sci. Lett. 84, 51-58.

Liu, P.-P., Zhou, M.-F., Chen, W.T., Boone, M., Cnudde, V., 2014. Using multiphase solid inclusions to constrain the origin of the Baima Fe-Ti-(V) oxide deposit, SW China. J. Petrol. 55, 951-976.

Martin, B., Kushiro, I., 1991. Immiscibility synthesis as an indication of cooling rates of basalts. J. Volcanol. Geotherm. Res. 45, 289-310.

Mathez, E.A., VanTongeren, J.A., Schweitzer, J., 2013. On the relationships between the Bushveld Complex and its felsic roof rocks, part 1: petrogenesis of Rooiberg and related felsites. Contrib. Mineral. Petrol. 166, 435-449.

Molyneux, T.G., 1974. A geological investigation of the Bushveld Complex in Sekhukhuneland and part of the Steelpoort valley. Trans. Geol. Soc. S. Afr. 77, 329-338.

Mungall, J.E., Su, S., 2005. Interfacial tension between magmatic sulfide and silicate liquids: constraints on kinetics of sulfide liquation and sulfide migration through silicate rocks. Earth Planet. Sci. Lett. 234, 135-149.

Namur, O., Charlier, B., Holness, M.B., 2012. Dual origin of Fe-Ti-P gabbros by immiscibility and fractional crystallization of evolved tholeiitic basalts in the Sept Iles layered intrusion. Lithos 154, 100-114.

Namur, O., Abily, B., Boudreau, A., Blanchette, F., Bush, J.W.M., Ceuleneer, G., Charlier, B., Donaldson, C.H., Higgins, M.D., Morata, D., Nielsen, T.F.D., O’Driscoll, B., Pang, K.-N., Peacock, T., Spandler, C., Toramaru, A., Veksler, I.V., 2015. Igneous layering in basaltic magma chambers. In: Charlier, B., et al. (Eds.), Layered Intrusions. Springer, Dordrecht, pp. 75-152.

Pang, K.N., Li, C., Zhou, M.F., Ripley, E.M., 2009. Mineral compositional constraints on petrogenesis and oxide ore genesis of the late Permian Panzhihua layered gabbroic intrusion, SW China. Lithos 110, 199-214.

Philpotts, A.R., 1982. Compositions of immiscible liquids in volcanic rocks. Contrib. Mineral. Petrol. 80, 201-218.

Pouchou, J.L., Pichoir, F., 1991. Quantitative analysis of homogeneous or stratified microvolumes applying the model "PAP". In: Electron Probe Quantification, pp. 31-75.

Reynolds, I., 1985. The nature and origin of titaniferous magnetite-rich layers in the Upper Zone of the Bushveld Complex: a review and synthesis. Econ. Geol. 80, 1089-1108.

Scoon, R.N., Mitchell, A.A., 1994. Discordant iron-rich ultramafic pegmatites in the Bushveld Complex and their relationship to iron-rich intercumulus and residual liquids. J. Petrol. 35 (4), 881-917.
Scoon, R.N., Mitchell, A.A., 2012. The Upper Zone of the Bushveld Complex at Roossenekal, South Africa: geochemical stratigraphy and evidence of multiple episodes of magma replenishment. S. Afr. J. Geol. 115, 515-534.

Tegner, C., Cawthorn, R.G., 2010. Iron in plagioclase in the Bushveld and Skaergaard intrusions: implications for iron contents in evolving basic magmas. Contrib. Mineral. Petrol. 159 (5), 719-730.

Tegner, C., Cawthorn, R.G., Kruger, F.J., 2006. Cyclicity in the Main and Upper Zones of the Bushveld Complex, South Africa: crystallization from a zoned magma sheet. J. Petrol. 47, 2257-2279.

Thy, P., Lesher, C.E., Tegner, C., 2009. The Skaergaard liquid line of descent revisited. Contrib. Mineral. Petrol. 157 (6), 735-747.

Toplis, M.J., Carroll, M.R., 1996. Differentiation of ferro-basaltic magmas under conditions open and closed to oxygen: implications for the Skaergaard intrusion and other natural systems. J. Petrol. 37 (4), 837-858.

VanTongeren, J.A., Mathez, E.A., 2012. Large-scale liquid immiscibility at the top of the Bushveld Complex, South Africa. Geology 40, 491-494.

VanTongeren, J.A., Mathez, E.A., 2013. Incoming magma composition and style of recharge below the Pyroxenite Marker, Eastern Bushveld Complex, South Africa. J. Petrol. 54, 1585-1605.

VanTongeren, J.A., Mathez, E.A., 2014. Rare earth element abundances in apatite in the Bushveld Complex-a consequence of the trapped liquid shift effect: COMMENT. Geology 42, e318.

VanTongeren, J.A., Mathez, E.A., Kelemen, P.B., 2010. A felsic end to Bushveld differentiation. J. Petrol. 51, 1891-1912.

Veksler, I.V., Charlier, B., 2015. Silicate liquid immiscibility in layered intrusions. In: Charlier, B., Namur, O., Latypov, R., Tegner, C. (Eds.), Layered Intrusions. Springer Geology, Dordrecht, pp. 229-258.

Veksler, I.V., Kahn, J., Franz, G., Dingwell, D.B., 2010. Interfacial tension between immiscible liquids in the system $\mathrm{K}_{2} \mathrm{O}-\mathrm{FeO}-\mathrm{Fe}_{2} \mathrm{O}_{3}-\mathrm{Al}_{2} \mathrm{O}_{3}-\mathrm{SiO}_{2}$ and implications for the kinetics of silicate melt unmixing. Am. Mineral. 95, 1679-1685.

von Gruenewaldt, G., 1973. The Main and Upper Zones of the Bushveld Complex in the Roossenekal area, eastern Transvaal. Trans. Geol. Soc. of S. Afr. 76, 207-227.

von Gruenewaldt, G., 1993. Ilmenite-apatite enrichments in the upper zone of the Bushveld Complex: a major titanium-rock phosphate resource. Int. Geol. Rev., 987-1000.

von Gruenewaldt, G., Klemm, D.D., Henckel, J., Dehm, R.M., 1985. Exsolution features in titanomagnetites from massive magnetite layers and their host rocks of the Upper Zone, eastern Bushveld Complex. Econ. Geol. 80 (4), 1049-1061.

Wager, L.R., Brown, G.M., 1968. Layered Igneous Rocks. Oliver and Boyd, Edinburgh, p. 588 .

Wilkinson, J.F.G., 1986. Classification and average chemical compositions of common basalts and andesites. J. Petrol. 27 (1), 31-62.

Zeh, A., Ovtcharova, M., Wilson, A.H., Schaltegger, U., 2015. The Bushveld Complex was emplaced and cooled in less than one million years - results of zirconology, and geotectonic implications. Earth Planet. Sci. Lett. 418, 103-114. 